\title{
The physicochemical, immunological and biological properties of rat pituitary and plasma LH
}

\author{
A. J. Leigh ${ }^{1}$, A. J. Chapman ${ }^{3}$, T. Shakil ${ }^{2}$ and C. A. Wilson ${ }^{1 *}$ \\ Department of ${ }^{1}$ Obstetrics and Gynaecology, and ${ }^{2}$ Department of Physiology, St George's Hospital \\ Medical School, London SW17 ORE, UK; and ${ }^{3}$ Department of Medicine, Queen Elizabeth Hospital, \\ Gateshead NE9 65X, UK
}

\begin{abstract}
A comparison was made between the properties of $\mathrm{LH}$ derived from female rat pituitary glands and plasma. Samples were collected from adult intact rats $5 \mathrm{~h}$ before or at the time of the pro-oestrous preovulatory LH surge; 27-day-old rats untreated or given 5 iu pregnant mares' serum gonadotrophin (PMSG) s.c. on day 25, which induced LH release $54 \mathrm{~h}$ later and adult ovariectomized rats untreated or primed with either $5 \mu \mathrm{g}$ oestradiol benzoate s.c. or $5 \mu$ g oestadiol benzoate followed $48 \mathrm{~h}$ later by $0.5 \mathrm{mg}$ progesterone s.c., which induced $\mathrm{LH}$ release $4-6 \mathrm{~h}$ later. All pituitary $\mathrm{LH}$ samples were totally bound to an anionic ion-exchange resin (DE52), while only a small proportion of the plasma LH was bound. Only $0-10 \%$ plasma LH obtained from intact, ovariectomized (with and without steroids) and untreated immature rats was bound, while a greater proportion of bound $\mathrm{LH}(36 \%)$ was noted in rats treated with PMSG. Gel filtration indicated only slight differences between pituitary and plasma $\mathrm{LH}$, the former eluting marginally earlier than whole plasma and the unbound and bound plasma forms derived after separation by DE52 resin. Affinity chromatography (Concanavalin A and Glycine maximus) showed that LH from both sources possesses high mannose oligosaccharides and that plasma LH does not bear terminal $\mathrm{N}$-acetyl galactosamine residues, although $20 \%$ of the pituitary form does. Plasma obtained from pro-oestrous rats had greater bioactivity than had pituitary LH in stimulating testosterone from Leydig cells and progesterone from granulosa cells in vitro, and inducing ovulation in immature rats in vivo. Leydig cell bioassays for LH in fractions obtained from ion-exchange separation indicate that steroidogenic activity of unbound plasma LH is greater than bound pituitary LH when they were collected at times of enhanced release. When release was inhibited (oestrogen-primed ovariectomized rats or immature rats), the steroidogenic activity of plasma and pituitary LH were similar and an acidic steroidogenic component was present in the plasma that was not recognized immunogenically as LH. In summary, pituitary LH undergoes a conversion on release into the plasma that involves a change in binding characteristics on an ion-exchange resin. In conditions when $\mathrm{LH}$ release is enhanced there is an increase in bioactivity of plasma LH owing to modification either by steroids or some other plasma factor(s) that perhaps influence the structure of LH directly or by steroids acting indirectly to alter $\mathrm{GnRH}$ release, which then modifies $\mathrm{LH}$ structure. These structural changes are minor and probably involve alterations in the glycosyl attachments.
\end{abstract}

\section{Introduction}

Campbell and co-workers (1978a, b) were the first to suggest that $\mathrm{LH}$ stored in the pituitary gland differs from circulatory LH. They based this hypothesis upon the difference in clearance rates between rat pituitary and plasma $\mathrm{LH}$, the latter possessing a shorter circulatory half-life. Reddy and Menon (1981) supported this with more direct evidence, showing that there were two forms of $\mathrm{LH}$ in the rat pituitary gland which

${ }^{*}$ Correspondence.

Revised manuscript received 8 February 1994. had different molecular weights, and that only the smaller, more active form was released into the plasma.

LH bioactivity depends on noncovalent subunit bonding and the attachment of appropriate glycoconjugate moieties, which consist of complex oligosaccharides with the potential to bind sialic acid or sulfate groups or both in chain-terminating positions (Keel and Grotjan, 1989; Wilson et al., 1990). The potential for variation in the molecular weight of $\mathrm{LH}$ is thought to reside in the oligosaccharide glycoconjugates (Chowdhury et al., 1982), although aggregation of LH molecules may partially account for heavier pituitary LH forms, since these heavier forms can be eliminated by ultracentrifugation (Keel 
and Grotjan, 1989). Variation in oligosaccharide structure and, in particular, the degree of terminal sialiation or sulfation confers net molecular charge heterogeneity; isoelectric focusing and chromatofocusing techniques will therefore separate the pituitary- and plasma-derived LH glycoforms according to their individual isoelectric points (pIs). Other investigators have reported between four and eight differentially charged glycoforms of rat and human LH in pituitary extracts and plasma using isoelectric focusing, while chromatofocusing and fast-phase liquid chromatography indicate the existence of 12-14 glycoforms with charge variance (Wakabayashi, 1977; Stockell-Hartree et al., 1985; Keel and Grotjan, 1989). Bioassays of human pituitary LH in vitro have indicated that there is a direct relationship between $\mathrm{pI}$ and bioactivity, and that the basic forms are more active (Lichtenberg et al., 1982).

It has been suggested that there is an alteration in $\mathrm{LH}$ structure on its release into the circulation, either in association with discharge from its 'storage pool' (Campbell et al., 1978a, b; Sardanons et al, 1987) or due to one or more agents present in the circulation that effect post-secretory alteration (Reddy and Menon, 1981; Wilson et al., 1985). As it is the plasma LH glycoforms that mediate actions at the target organ, their structures are of primary significance.

We have compared the properties of rat pituitary- and plasma-derived LH using ion-exchange, gel filtration and affinity chromatography and have confirmed that a change in glycoform composition occurs when $\mathrm{LH}$ is released from the pituitary gland into the circulation, and that this is paralleled by changes in bioactivity. The possibility that the endocrine milieu influences this change was investigated by using different animal models to test whether circulatory agents influence the relative distribution of the different glycoforms.

\section{Methods}

\section{Animals}

Female Wistar rats bred at St George's Hospital Medical School, London were housed under a photoperiod of $12 \mathrm{~h}$ light:12 h dark (lights on at 07:00 h). Rats showing at least three regular oestrous cycles were either used intact or were ovariectomized under anaesthesia with halothane (Fluothane: ICI Pharmaceuticals Ltd, Macclesfield) and nitrous oxide, and allowed a recovery and stabilization period of 3 weeks before use. All adult rats were aged between 10 and 15 weeks, and weighed $250-300 \mathrm{~g}$. Immature rats providing pituitary and plasma samples were 25 days old, and those used to assess the bioactivity of the samples were 22-23 days old.

\section{Treatments and times of sample collection}

Intact rats were killed on the day of pro-oestrus either $5 \mathrm{~h}$ before the expected preovulatory LH surge $(14: 00 \mathrm{~h})$ when pituitary glands were collected, or at the expected time of the LH surge $(19: 00 \mathrm{~h})$ when pituitary glands and trunk blood were collected. Immature rats received either 5 iu pregnant mares' serum gonadotrophin (PMSG; Folligon: Intervet (UK) Ltd, Cambridge) $0.1 \mathrm{ml}$ saline per rat s.c. or $0.1 \mathrm{ml}$ saline per rat at 25 days of age. These rats were killed at 19:00 h on day 27 (time of the anticipated LH surge induced by PMSG). Adult ovariectomized rats were treated s.c. with either $5 \mu \mathrm{g}$ oestradiol benzoate per rat in corn oil vehicle (Sigma Chemical Co., Poole, Dorset) or with $5 \mu \mathrm{g}$ oestradiol benzoate per rat followed $48 \mathrm{~h}$ later by an injection s.c. of $0.5 \mathrm{mg}$ progesterone per rat (Sigma Chemical Co.) or $0.1 \mathrm{ml}$ vehicle per rat. All ovariectomized rats were killed $54 \mathrm{~h}$ after treatment with oil or oestradiol benzoate (i.e. $4 \mathrm{~h}$ after the injection of progesterone at the expected time of the steroid-induced LH surge).

\section{Samples}

All animals were killed by decapitation. Trunk blood was collected into heparinized polypropylene tubes and immediately centrifuged at $400 \mathrm{~g}$ at $4^{\circ} \mathrm{C}$ for $15 \mathrm{~min}$, and supernatant plasma was stored at $-20^{\circ} \mathrm{C}$. Plasma obtained from steroidtreated ovariectomized rats was mixed with $5 \%$ purified charcoal (BDH Lab. Supplies, Merck Ltd, Lutterworth, Leics) for $30 \mathrm{~min}$ at room temperature; the mixture was then centrifuged at $400 \mathrm{~g}$ for $15 \mathrm{~min}$ and the supernatant was decanted from the charcoal pellet. This procedure removed the steroids present in the sample. Pituitary glands were removed and homogenized in $1 \mathrm{ml}$ of $0.5 \mathrm{~mol}$ phosphate-buffered saline $1^{-1}$ containing $100 \mathrm{iu}$ Trasylol ml ${ }^{-1}$ (Bayer, Leverkusen) at $\mathrm{pH}$ 7.4. The homogenate was then centrifuged for $5 \mathrm{~min}$ and the supernatant stored at $-20^{\circ} \mathrm{C}$.

\section{Chromatographic techniques}

Ion-exchange chromatography. Pooled plasma $(8-12 \mathrm{ml}$, consisting of samples of equal volume obtained from 3-4 rats), or $0.2 \mathrm{ml}$ of pituitary extract (i.e. the equivalent of a fifth of a pituitary) were dialysed overnight (Spectrum Medical Industries Inc., CA, MWCO 12 000-14 000) against $1.0 \mathrm{l}$ of $5 \mathrm{mmol}$ ammonium hydrogen carbonate $\mathrm{I}^{-1}\left(\mathrm{NH}_{4} \mathrm{HCO}_{3}\right.$ at $\mathrm{pH} 7.4$ at $4^{\circ} \mathrm{C}$ ). The samples were drawn onto a column of DE52 (diethylaminoethyl cellulose; Whatman Biosystems Ltd, Maidstone) bed volume $50 \mathrm{ml}$, at a rate of $10 \mathrm{ml} \mathrm{h}^{-1}$. The

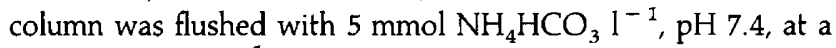
rate of $10 \mathrm{ml} \mathrm{h}^{-1}$ and $2 \mathrm{ml}$ fractions were collected every $12 \mathrm{~min}$. At fraction 30 , a salt gradient $\left(0-200 \mathrm{mmol} \mathrm{NaCl} \mathrm{l}^{-1}\right)$ in $5 \mathrm{mmol} \mathrm{NH} \mathrm{HCO}_{3} \mathrm{l}^{-1}$, $\mathrm{pH} 7.4$ was applied and developed for the duration of fractionation. A total of 100 or 120 fractions of $2 \mathrm{ml}$ each were collected. Aliquots $(50 \mu \mathrm{l})$ from each fraction were assayed in duplicate by radioimmunoassay and, in some cases, by mouse Leydig cell bioassay. It was found that a start sample containing more than $60 \mathrm{ng}$ LH provided sufficient LH for measurement after fractionation. Recovery was nearly $100 \%$ for pituitary $\mathrm{LH}$ and between $60 \%$ and $90 \%$ for plasma $\mathrm{LH}$, according to both radioimmunoassay and Leydig cell bioassay (Table 1 ). The reduced recovery of the plasma $\mathrm{LH}$ appeared to be due to a tightly absorbed proportion of LH that eluted only after application of $1 \mathrm{~mol} \mathrm{NaCl} 1^{-1}$. This concentration of salt did not interfere with the immunoassay but was toxic to the Leydig cells. These fractions need to be de-salted to assess the bioactivity of this tightly bound component.

Gel filtration. A Sephadex G100 column (Pharmacia Ltd, Milton Keynes), $1 \mathrm{~cm} \times 100 \mathrm{~cm}$, was equilibrated in $0.01 \mathrm{~mol}$ 
Tris-HCl running buffer $\mathrm{I}^{-1}, \mathrm{pH}$ 7.4. Plasma samples and pooled ion-exchange fractions were lyophilized and reconstituted in $0.5 \mathrm{ml}$ of running buffer, and then dialysed overnight against $1.0 \mathrm{l}$ running buffer. Pituitary extract $(0.2 \mathrm{ml})$ was dialysed similarly. Samples were applied to the column at a rate of $10 \mathrm{ml} \mathrm{h}^{-1}$ and fractions collected $(2.0 \mathrm{ml}$ in $12 \mathrm{~min})$. BSA $(67 \mathrm{kDa})$, carbonic anhydrase $(29 \mathrm{kDa})$ and cytochrome $\mathrm{C}$ ( $12 \mathrm{kDa}$ ) were used as molecular size markers and after they had eluted absorption measurements were taken at $280 \mathrm{~nm}$. Recovery was between 85 and $100 \%$.

Affinity chromatography. All samples consisted of pooled fractions obtained from ion-exchange separation. These were dialysed overnight against 1.01 of running buffer $(0.1 \mathrm{~mol}$ Tris- $\mathrm{HCl} \mathrm{I}{ }^{-1}, \mathrm{pH} 7.4,0.14 \mathrm{~mol} \mathrm{NaCl} \mathrm{I}{ }^{-1}, 1 \%$ BSA, $0.1 \%$ Thiomersal, $1 \mathrm{mmol} \mathrm{MnCl}_{2} 1^{-1}, 1 \mathrm{mmol} \mathrm{CaCl} \mathrm{l}^{-1}, 1 \mathrm{mmol}$ $\left.\mathrm{MgCl}_{2} \mathrm{l}^{-1}\right)$. Samples were applied at a rate of $2 \mathrm{ml} \mathrm{h}^{-1}$ to a Concanavalin-A-sepharose (Con A) column, bed volume $5 \mathrm{ml}$, which was connected in series to a Soya bean agglutininsepharose Glycine maximus (Glycine maximus) column, bed volume $10 \mathrm{ml}$ (lectins obtained from Sigma Chemical $\mathrm{Co}$.).

Once the sample had been applied, the Con A column was flushed with running buffer $\left(0.1 \mathrm{~mol}\right.$ Tris $\left.-\mathrm{HCl} \mathrm{l}^{-1}, \mathrm{pH} 7.4\right)$ at $2 \mathrm{ml} \mathrm{h}^{-1}$ for at least 10 fractions, followed by an addition of $200 \mathrm{mmol}$ mannose $1^{-1}$ (methyl $\alpha$-D-glucopyranoside; Sigma Chemical $C_{0}$.) in running buffer at $10 \mathrm{ml} \mathrm{h}^{-1}$. At the time of applying the mannose, the Glycine maximus column was connected in series to the Con A column and at fraction number 60 the mannose buffer was replaced by $200 \mathrm{mmol}$ D-galactose $1^{-1}$ in running buffer, also applied at $10 \mathrm{ml} \mathrm{h}^{-1}$ (Sigma Chemical $\mathrm{Co}_{\text {.). }}$. In all cases 120 fractions of $2 \mathrm{ml}$ were collected. Recovery from the Con A-Glycine maximus system was $59 \pm 8 \%(n=6)$. This level of recovery is to be expected at the scale of separation used (Pharmacia, 1991).

\section{Assays for $L H$}

Radioimmunoassay. LH concentrations were measured in duplicate in $50 \mu \mathrm{l}$ aliquots of the chromatographic fractions, in $10 \mu \mathrm{l}$ of plasma and pituitary extract (the pituitary extract was diluted 1:500), using reagents provided by the National Hormone and Pituitary Program (Baltimore, MD) consisting of the NIH-rLH-RP3 standard and NIH-rLH-S10 antibody. The sensitivity of the assay was $1.25 \mathrm{ng} \mathrm{ml}^{-1}$ and the intra-assay and interassay coefficients of variance were $8 \%(n=20)$ and $10.5 \%$ ( $n=6$ for each dose), respectively, at three dosages: 25,100 and $400 \mathrm{ng}$. The presence of the buffers used in the various chromatographic separations $\left(\mathrm{NaCl}, 5-200 \mathrm{mmol} \mathrm{l}^{-1}\right.$ and $1 \mathrm{~mol} \mathrm{1} \mathrm{l}^{-1}$; galactose, $200 \mathrm{mmol} \mathrm{l}^{-1}$; and mannose, $200 \mathrm{mmol} \mathrm{I}^{-1}$ ) did not interfere with the assay, and standard curves were superimposable in the absence and presence of these solutions.

The Leydig (interstitial) cell bioassay. The assay was modified from the method of van Damme et al. (1974). Samples of plasma $(50 \mu \mathrm{l})$ and pituitary extract $(50 \mu \mathrm{l}$, diluted $1: 500)$, or $50 \mu \mathrm{l}$ of fractions from the anionic exchange separation were assayed in duplicate in well plates ( 96 wells, $250 \mu \mathrm{l}$ capacity; Becton Dickinson, Lincoln Park, NJ). Leydig cells were obtained from 21-24-day-old male B6 mice (bred at St George's Hospital Medical School), and $150 \mu \mathrm{l}$ of a suspension containing $5 \times 10^{6} \mathrm{cells} \mathrm{ml}^{-1}$ was added to each well and incubated for $3 \mathrm{~h}$ at $37^{\circ} \mathrm{C}$ in an oxygenated environment. The cells were then killed by placing the well plates at $-80^{\circ} \mathrm{C}$. Comparison of data from assays performed in parallel with the method described by van Damme et al. (1974), in which cells were killed at $100^{\circ} \mathrm{C}$, showed consistently similar results. Samples of the incubate $(50 \mu \mathrm{l})$ were assayed in duplicate for testosterone using testosterone antibody No. 505 and $\left[{ }^{125} \mathrm{I}\right]$ testosterone (generously supplied by the MRC Reproductive Biology Unit, Edinburgh). The intra-assay and interassay coefficients of variance were 8.7 and $11.4 \%$, respectively, and the sensitivity was I ng ml-1.

\section{Stimulation of progesterone production by $L H$}

Dissected rat ovarian follicles ( $\geq 400 \mu \mathrm{m}$ diameter) were placed in $1 \times$ minimum essential medium containing $20 \mathrm{mmol}$ Hepes buffer $1^{-1}, 100 \mathrm{U}$ penicillin $\mathrm{ml}^{-1}$ and $100 \mu \mathrm{g}$ streptomycin sulfate $\mathrm{ml}^{-1}$. The follicles were ruptured and the granulosa cells dispersed by passing the cellular suspension through a 25-gauge needle and recovered by centrifugation. They were washed twice in McCoy's $5 \mathrm{~A}$ culture medium

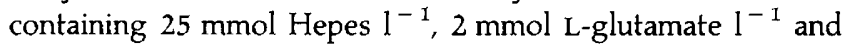
$0.01 \%$ BSA (all from Sigma Chemical Co.), and then plated out in $1 \mathrm{ml}$ aliquots at a concentration of $3 \times 10^{5}$ cells $\mathrm{ml}^{-1}$. Cell viability was $>95 \%$, as determined by the trypan blue exclusion test. Plasma $(10 \mu \mathrm{l})$ or pituitary extract $(50 \mu \mathrm{l}$, diluted 1:500) was added to $1 \mathrm{ml}$ of the cell cultures and incubated for $48 \mathrm{~h}$ at $37^{\circ} \mathrm{C}$ in a humidified atmosphere of $95 \% \mathrm{O}_{2}: 5 \% \mathrm{CO}_{2}$. Samples were stored at $-20^{\circ} \mathrm{C}$ for progesterone radioimmunoassay (Immunodiagnostic Systems Ltd, Tyne and Wear). This assay has been validated for measuring progesterone in both plasma and culture medium.

\section{Ovulatory activity of $\mathrm{LH}$}

PMSG induces an endogenous LH surge $54 \mathrm{~h}$ after administration, followed by ovulation the next day in immature rats. However, this occurs only after the rats have achieved a certain degree of maturity (Buckingham and Wilson, 1985); in our present Wistar rat colony this occurs on day 25 when the rats have a bodymass of more than $55 \mathrm{~g}$. In younger lighter rats, PMSG is less effective and using 22-23-day-old females weighing less than $55 \mathrm{~g}$, administration of PMSG induces only a small proportion to ovulate with no rise in immunoactive plasma LH at the expected time of the surge in the nonovulating animals (untreated rats on day 25 at 19:00 h, $1.80 \pm 0.2(n=10)$; PMSG-treated rats, $2.66 \pm 0.4(n=16) \mathrm{ng}$

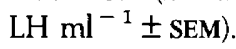

In these experiments, therefore, 22-23-day-old female rats weighing between 45 and $54 \mathrm{~g}$ were injected s.c. with 5 iu PMSG; 52-54 h later they received an injection i.v. into the tail vein of one of the following: $0.5 \mathrm{ml}$ saline, $0.2-1.0 \mathrm{ml}$ plasma (collected at 19:00 $\mathrm{h}$ from pro-oestrous adult rats and dialysed against $1 \mathrm{l}$ isotonic saline for $24 \mathrm{~h}$ ), or $0.5 \mathrm{ml}$ of similarly dialysed and diluted extracts of pituitaries (collected at 14:00 h on the day of pro-oestrus). All the samples had been assayed 
A. J. Leigh et al.

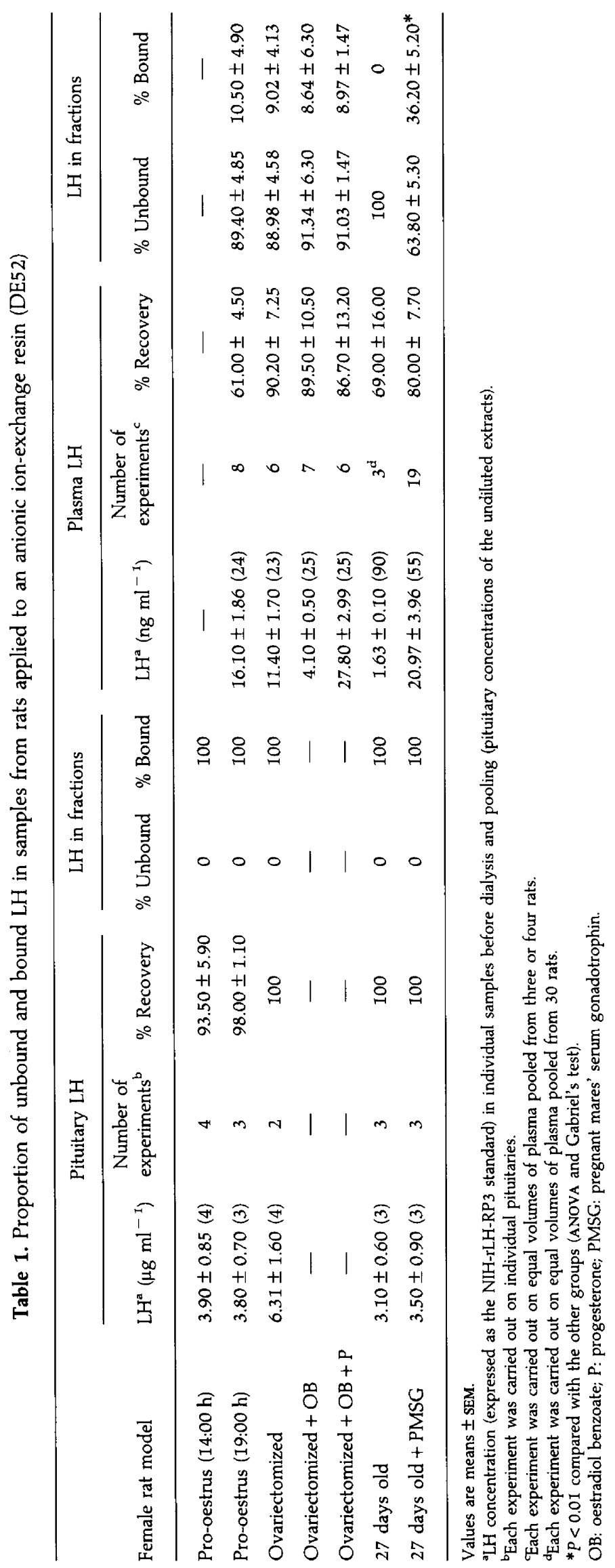


Table 2. Comparison of the bioactivity of pro-oestrous pituitary and plasma LH in rats

\begin{tabular}{|c|c|c|c|c|}
\hline Pro-oestrous samples & $\begin{array}{l}\text { Immunogenic LH } \\
\left(\mu \mathrm{g} \mathrm{ml}^{-1}\right)\end{array}$ & $\begin{array}{l}\text { LH applied to } \\
\text { cells (ng) }\end{array}$ & $\begin{array}{c}\text { Testosterone } \\
\left(\mu \mathrm{mol} \mathrm{l}^{-1} \mathrm{ng}^{-1} \mathrm{LH}\right)\end{array}$ & $\begin{array}{c}\text { Progesterone } \\
\left(\mathrm{nmol} \mathrm{l} \mathrm{I}^{-1} \mathrm{ng}^{-1} \mathrm{LH}\right)\end{array}$ \\
\hline Plasma at $19: 00 \mathrm{~h}(7)^{\mathrm{a}}$ & $24.1 \times 10^{3} \pm 4.9$ & $0.24 \pm 0.06$ & $169.6 \pm 55.3$ & $113.0 \pm 14.7$ \\
\hline Pituitaries at $19: 00 \mathrm{~h}(5)^{\mathrm{b}}$ & $5.39 \pm 0.64$ & $0.54 \pm 0.06$ & $68.25 \pm 10.7$ & $54.78 \pm 4.9$ \\
\hline Pituitaries at $14: 00 \mathrm{~h}(5)^{\mathrm{b}}$ & $6.19 \pm 1.16$ & $0.62 \pm 0.12$ & $60.05 \pm 10.8$ & $56.64 \pm 11.56$ \\
\hline Ratio of plasma activity:pituitary activity & - & - & $2.65: 1$ & 2.03:1 \\
\hline
\end{tabular}

Values are means \pm SEM.

aplasma LH was applied at $10 \mu \mathrm{l}$.

${ }^{b}$ Pituitary extracts were applied after 1:500 dilution at $50 \mu \mathrm{l}$.

for LH by radioimmunoassay and the variable volumes of plasma and dilutions of pituitary extract were used to administer graded doses of LH expressed in terms of the NIH-LHRP3 standard. The day after the LH injection, the animals were killed and the oviducts inspected for the presence of eggs.

\section{Chromatographic recoveries}

Chromatography results are presented in relation to the sample applied to the column. The effect of the various procedures carried out before the samples were applied (i.e. dialysis, lyophilization and charcoal treatment) have not been taken into account, and it is possible that they may have had a selective effect on LH forms or have damaged a bioactive moiety. Recovery of the immunoactive LH after dialysis against the three chromatographic buffers (i.e. $5 \mathrm{mmol}$ $\mathrm{NH}_{4} \mathrm{HCO}_{3} \mathrm{l}^{-1}, 0.01 \mathrm{~mol}$ Tris- $\mathrm{HCl} \mathrm{l^{-1 }}$ and the lectin Tris buffer) was noted and was usually complete, with never more than a $10 \%$ loss in some plasma samples.

\section{Statistical analyses}

Comparison of the percentage proportion of LH binding to the anion-exchange column (Table $\mathrm{I}$ ) and the bioactivity of $\mathrm{LH}$ samples (Table 2) was made by ANOVA followed by Gabriel's multiple comparison test between groups of unequal size. Correlation between LH concentration and stimulation of progesterone was assessed by Pearson's test, and comparison of the number of ovulating rats after administration of the $\mathrm{LH}$ samples by Fisher's tables.

\section{Results}

\section{Ion-exchange chromatography}

$\mathrm{LH}$ extracted from pituitaries of pro-oestrous (at $14: 00 \mathrm{~h}$ or 19:00 h), ovariectomized or 27-day-old female rats and applied to a DE52 anionic ion-exchange resin were all totally bound and eluted only following application of a $0-200 \mathrm{mmol} \mathrm{NaCl}$ $\mathrm{I}^{-1}$ gradient (see Table 1). The ratio of the steroidogenic biocompetence (B) to the immunoreactive (I) amount of $\mathrm{LH}$ (i.e. B:I) was 0.2:1, 0.8:1 and 0.8:1 in three different profiles of pro-oestrous pituitary glands (the first is shown in Fig. 1). In contrast, when plasma LH was applied to the anion-exchange resin, most of it was detected in fractions collected before application of the salt gradient, and so appeared to be a form that did not bind to the resin. Figure 2 illustrates one such profile and Table 1 shows that in eight pro-oestrous plasma LH profiles $89.40 \pm 4.85 \%$ of the total recovered was unbound. To verify that the detection of unbound LH was not due to saturation of column-binding capacity by other plasma proteins, pooled fractions containing the 'unbound' form were passed through a fresh column and found to remain unbound. The immuno- and bioassay results of the LH present in the fraction were compared and, again in contrast to the pituitary $\mathrm{LH}$, plasma $\mathrm{LH}$ was found to have greater steroidogenic than immunogenic activity, with a B:I ratio of 3:1, 1.5:1 and 5:1 in three profiles (the first is illustrated in Fig. 2).

Comparisons have also been made of bioassay and immunoassay results of the LH profiles obtained from the plasma of untreated immature female rats, ovariectomized adults and ovariectomized adults treated with either $5 \mu \mathrm{g}$ oestradiol benzoate, which reduced circulating concentrations of LH in the animal, or $5 \mu \mathrm{g}$ oestradiol benzoate followed by $0.5 \mathrm{mg}$ progesterone, which induced an increase in LH release (see Table I for plasma LH concentrations). All of the ovariectomized adult plasma samples were treated with charcoal to remove endogenous steroids before they were applied to the anion-exchange column. The B:I ratio altered with the endocrine milieu; it was $0.8: 1$ in the immature plasma sample, $2: 1$ in the adult ovariectomized sample, $0.8: 1$ in the sample treated with oestradiol benzoate and 5:1 in the sample treated with oestradiol benzoate and progesterone. In the anion-exchange profiles obtained from the immature and ovariectomized group treated with oestradiol benzoate, in which LH release is at its lowest, a tightly bound steroidogenic component was revealed that was not detected by the radioimmunoassay (Fig. 3b, c).

Table 1 summarizes the proportion of unbound and bound LH (expressed as percentages of the total LH in the fractions) in plasma and pituitaries of female rats in a variety of endocrine conditions (i.e. intact adults on the day of pro-oestrus, untreated and steroid-treated ovariectomized adults, and untreated and PMSG-treated immature rats). All the pituitary LH anion-exchange profiles were similar, with $100 \% \mathrm{LH}$ 


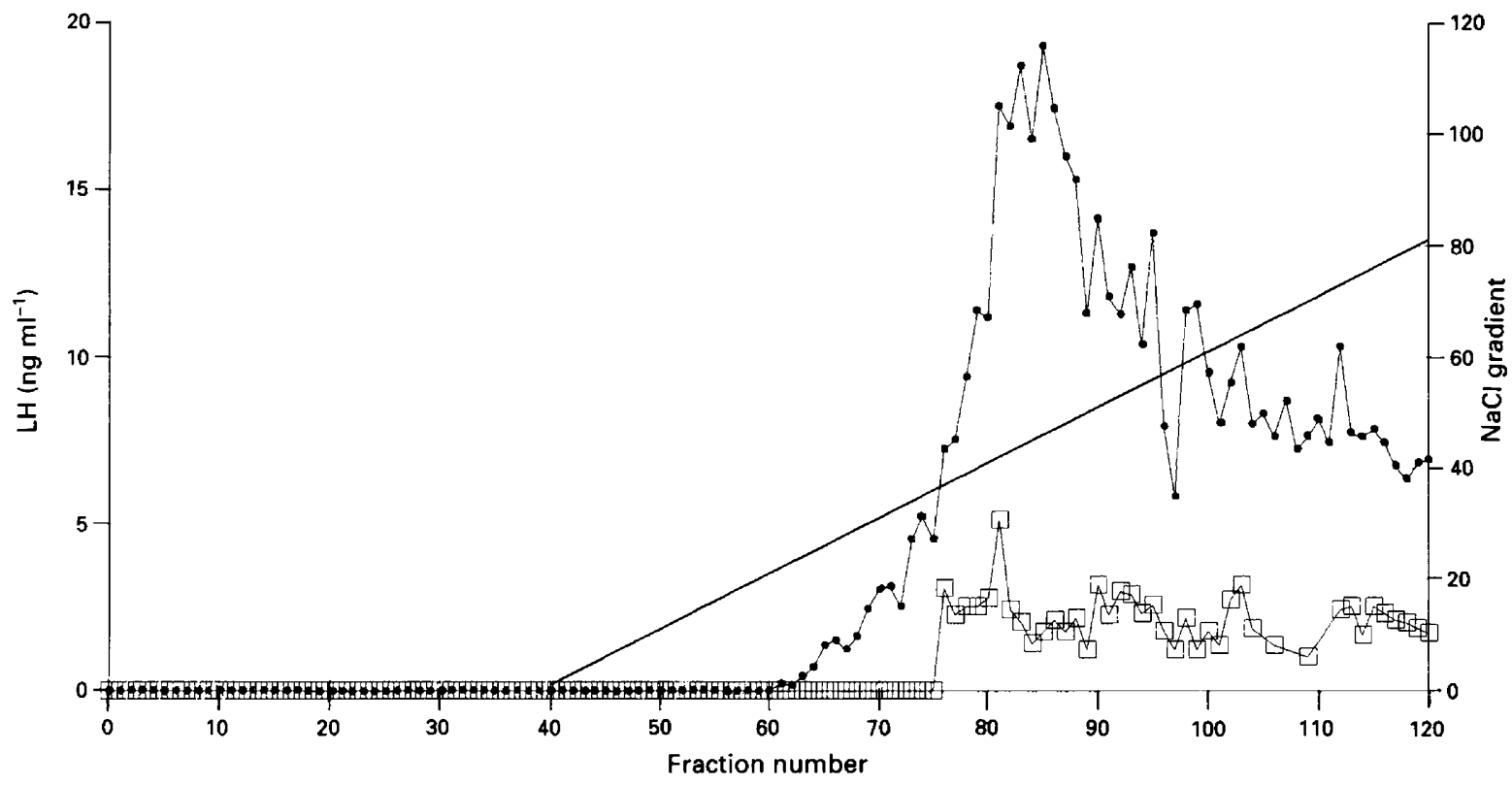

Fig. 1. Immuno- and biogenic ion-exchange profiles of pro-oestrous pituitary LH in rats. An extract (0.2 ml) from a pro-oestrous rat pituitary was applied to the DE52 ion-exchange column after overnight dialysis. An $\mathrm{NaCl}$ gradient $\left(200 \mathrm{mmol}^{-1}\right)$ was applied at fraction 40 . LH in the fractions was detected by radioimmunoassay $(\bullet)$ and Leydig cell bioassay ( $\square$ ).

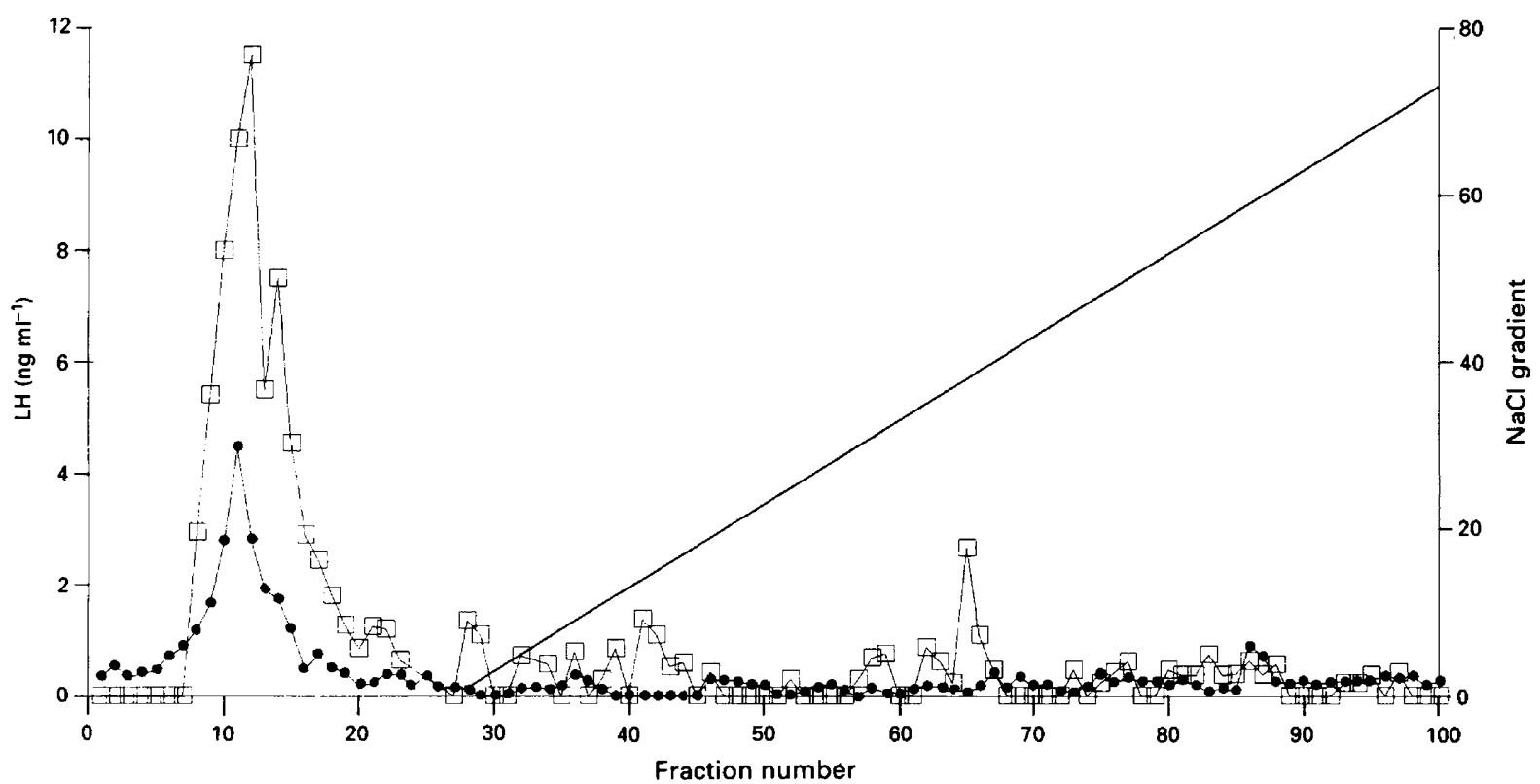

Fig. 2. Immuno- and biogenic ion-exchange profiles of pro-oestrous plasma LH in rats. Pooled pro-oestrous plasma collected at 19:00 $\mathrm{h}$ on the day of pro-oestrus was applied to the DE52 ion-exchange column after overnight dialysis. An $\mathrm{NaCl}$ gradient $\left(200 \mathrm{mmol} \mathrm{I^{-1 }}\right)$ was applied at fraction 30 . LH in the fractions detected by radioimmunoassay $(\bullet)$ and Leydig cell bioassay ( $\square$ ).

binding. Plasma LH profiles of adult rats and untreated immature rats were also similar to each other, with no significant difference in the relative proportions of bound to unbound LH. Steroid treatment in ovariectomized rats, either exerting a negative feedback effect on $\mathrm{LH}$ release $(5 \mu \mathrm{g}$ oestradiol benzoate alone) or a positive feedback effect $(5 \mu \mathrm{g}$ oestradiol benzoate plus $0.5 \mathrm{mg}$ progesterone), had no effect on the relative proportions. However, when immature rats were treated with PMSG their plasma LH profile showed a significantly greater $(P<0.01)$ proportion of the bound form compared with the other groups.

\section{Gel filtration}

Gel filtration disclosed that pro-oestrous pituitary-derived 

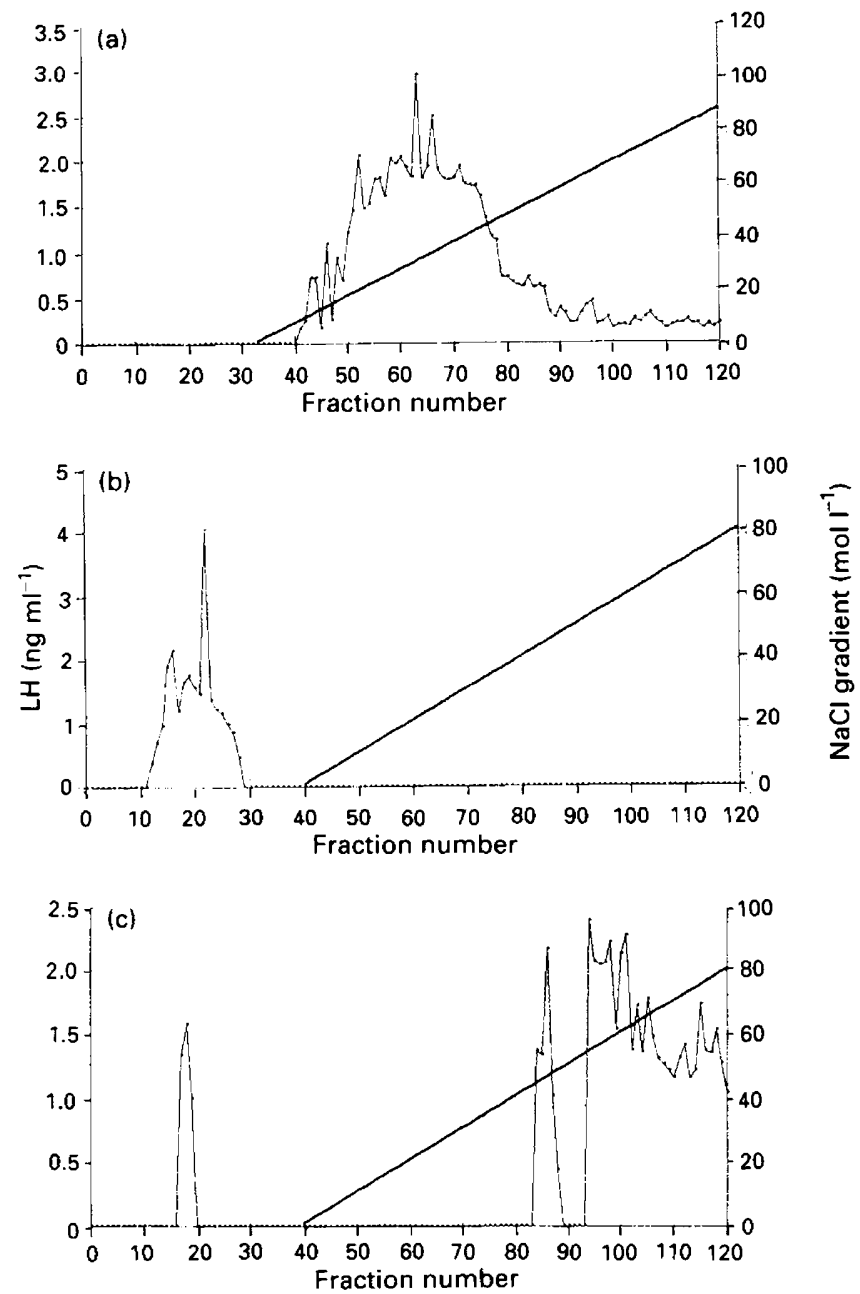

Fig. 3. Ion-exchange profiles of untreated immature female rat pituitary and plasma LH. (a) Immature rat pituitary extract was applied to the DE52 ion-exchange column after overnight dialysis. LH in the fractions was detected by radioimmunoassay. Immature rat plasma extract was applied to the DE52 column after overnight dialysis and $\mathrm{LH}$ in the fractions was detected (b) by radioimmunoassay and (c) by Leydig cell bioassay. An $\mathrm{NaCl}$ gradient $\left(200 \mathrm{mmol}^{-1}\right.$ ) was applied at fraction 32 for pituitary $\mathrm{LH}$ and at fraction 40 for plasma LH.

LH eluted from the column marginally earlier than did pro-oestrous plasma-derived LH. Pooled anion-exchange fractions containing either unbound or bound LH (obtained after ion-exchange separation of plasma taken from PMSGtreated immature rats) eluted from the G100 column in slightly different regions, the unbound form co-eluting with the unfractionated pro-oestrous plasma peak and the bound form eluting a little later. Thus, the bound LH from a plasma source did not correspond to the pituitary-derived bound LH (see Fig. 4).

\section{Affinity chromatography}

Pooled fractions obtained after anion-exchange chromatography containing either unbound $\mathrm{LH}$ from pro-oestrous plasma or bound LH from pro-oestrous pituitary glands were applied to two lectin columns in series (Con A followed by Glycine maximus). Figure 5 shows the mean of three profiles, where the $\mathrm{LH}$ in the fractions is expressed as a percentage of the total $\mathrm{LH}$ recovered. Both pituitary and plasma LH were totally adsorbed to Con A and eluted only after application of $200 \mathrm{mmol}$ mannose buffer $\mathrm{I}^{-1}$. The mean elution volume for onset and peak concentration following application of the mannose was $22.7 \pm 0.7$ (onset) and $31.0 \pm 0.7$ (peak) $\mathrm{ml}$ for pituitary $\mathrm{LH}$ $(n=3)$ and $19.7 \pm 0.9$ (onset) and $28.7 \pm 0.7$ (peak) $\mathrm{ml}$ for plasma LH $(n=3)$. Little or none of the plasma LH bound to the Glycine maximus column, but $18.8 \pm 5 \%$ of the pituitary $\mathrm{LH}$ was eluted from this column after addition of $200 \mathrm{mmol}$ galactose $1^{-1}$, suggesting that a terminal galactose residue is exposed in a proportion of the pituitary LH forms but not in those of the plasma.

\section{Bioactivity}

Table 2 shows the LH bioactivity of pro-oestrous pituitary and plasma samples as assessed by testosterone stimulation from Leydig cells and progesterone stimulation from granulosa cells. Pituitary glands, whether collected in pro-oestrus at 14:00 h (before the LH surge) or at 19:00 h (at the time of the LH surge), had similar steroidogenic bioactivities to each other and were approximately half as active as plasma LH collected at 19:00 h. Plasma LH stimulated the production of testosterone (van Damme et al., 1974) and progesterone $(r=0.88$; $P<0.02)$ in a dose-dependent manner.

An immature rat model was used for testing the ovulatory activity of LH samples in vivo. Table 3 shows that PMSG followed by a dose of saline induced ovulation in only $22 \%$ of the 22-23-day-old rats weighing $49.8 \pm 0.87 \mathrm{~g}$. Administration of pituitary or plasma-derived LH samples i.v. over a range of doses revealed that the plasma LH was approximately five times more active, since it induced a significant number of ovulations compared with saline at $20 \mathrm{ng} \mathrm{LH}$ per rat, while a similar effect by pituitary LH was noted only at $100 \mathrm{ng}$ LH per rat.

\section{Discussion}

LH consists of two noncovalently linked peptide chains, designated $\alpha$ and $\beta$ subunits. There are two asparagine $N$-linked oligosaccharide moieties at positions 52 and 78 on the $\alpha$ subunit and one at position 13 or 30 (in the human) on the $\beta$ subunit (Wilson et al., 1990). Carbohydrate structures are $N$-linked to the $\beta$-amide nitrogen of asparagine (Asn) via an $\mathrm{N}$-acetyl-D-glucosamine moiety (GlcNAc) and typically possess a common pentasaccharide core consisting of two GlcNAc and three mannose (Man) residues: Asn-GlcNAc-GlcNAc- $\beta 1-M a n-$ B1-(Mana1-6)-Mana1-3. The GlcNAc nearest the Asn may be fucosylated. There are two or more sugar chains attached to the Man residues via GlcNAc and these can be very variable in structure since besides GlcNAc, Man and fucose they may contain $\mathrm{N}$-acetyl-D-galactosamine (GalNAc) and $\mathrm{N}$-acetyl neuraminic acid (NeuNAc; sialic acid). The oligosaccharides are all electrochemically neutral except those bearing NeuNAc or sulfate groups on their terminal sugars; sulfated oligosaccharides predominate in LH. Heterogeneity of the sugar structures and branch-terminating radicals are thought to 


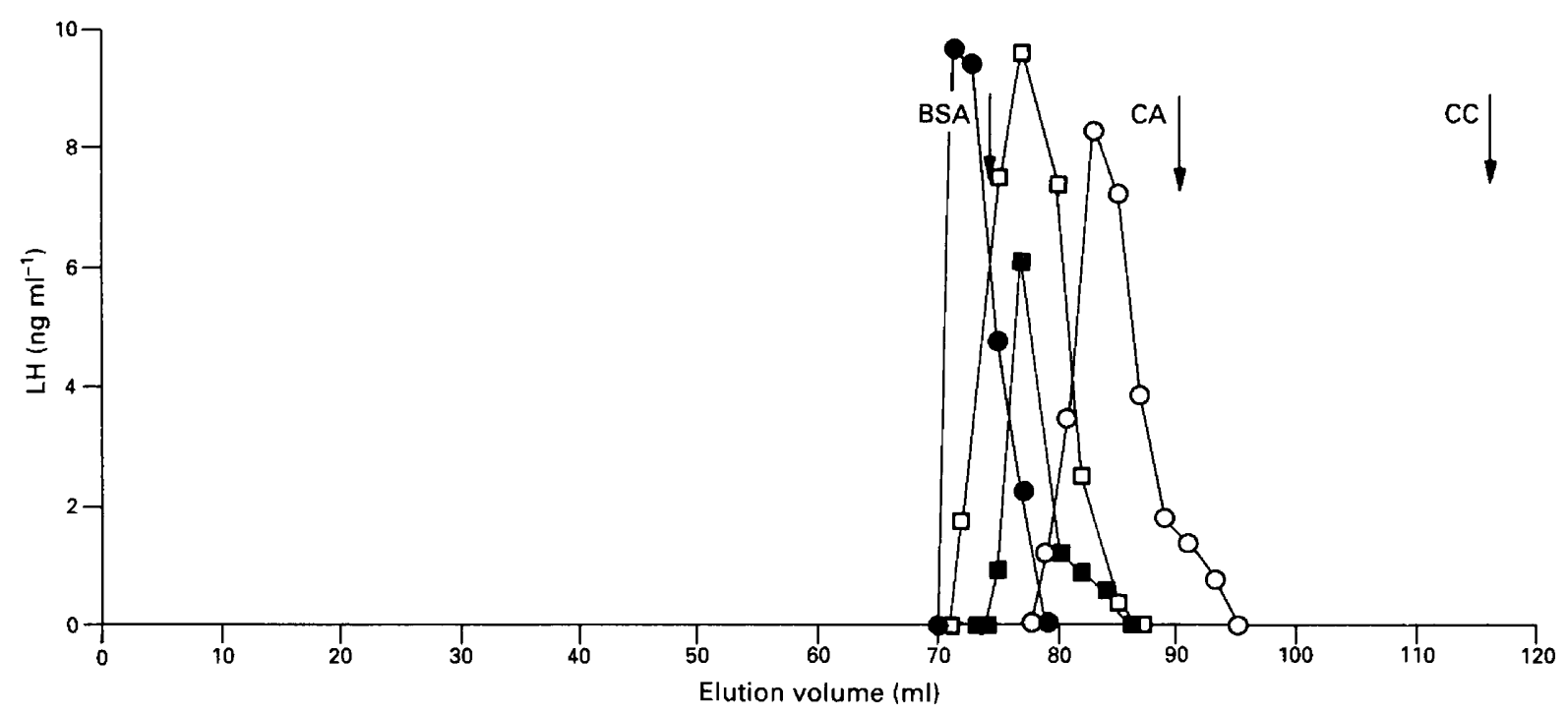

Fig. 4. G100 profile of rat pituitary and plasma LH. Pooled ion-exchange fractions of plasma ( $\square$ ) were lyophilized and reconstituted in $0.5 \mathrm{ml}$ of $0.01 \mathrm{~mol}$ Tris- $\mathrm{HCl} \mathrm{l} \mathrm{l}^{-1}(\mathrm{pH} 7.4)$ and dialysed. These samples and $0.2 \mathrm{ml}$ pituitary extracts (-) were applied to the Sephadex G100 column, and the presence of LH was detected in the fractions by radioimmunoassay. Unbound $(\boldsymbol{\sigma})$ and bound $(0)$ plasma from the DE52 separation were obtained from 27-day-old female rats treated with pregnant mares' serum gonadotrophin, which contain significant amounts of both (see Table 1). CA: carbonic anhydrase; CC: cytochrome C.

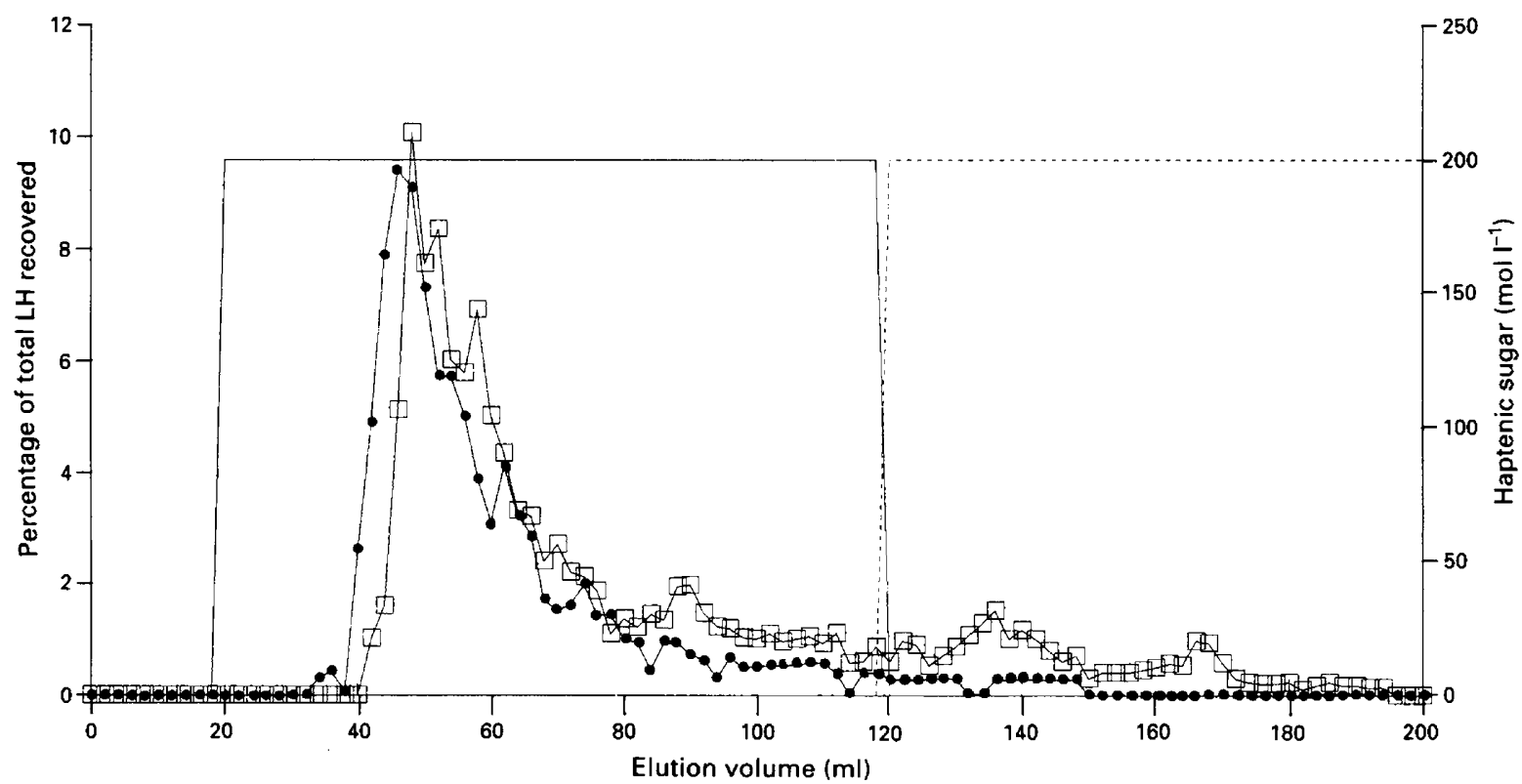

Fig. 5. Binding profiles of pro-oestrous pituitary and plasma LH on Concanavalin A and Glycine maximus lectin columns. Pooled DE52 fractions containing either unbound plasma LH or bound pituitary LH were dialysed and applied to the Concanavalin A column. Mannose $\left(200 \mathrm{mmol} \mathrm{l}^{-1}\right.$; solid line) was applied at fraction $10(20 \mathrm{ml})$, at which point the Concanavalin $A$ was linked to the Glycine maximus column. At fraction 60 (120 ml), galactose $\left(200 \mathrm{mmol} 1^{-1}\right.$; dotted line) was applied. LH in the fractions was detected by radioimmunoassay. The graphs show the mean of three profiles of plasma LH expressed as a percentage of the total LH recovered ( $\bullet$ ) and the mean of three profiles of pituitary LH expressed as a percentage of the total LH recovered ( $\square$ ).

underlie heterogeneity in LH structure (Baenziger and Green, 1988; Grotjan, 1989).

Several pituitary and plasma LH glycoforms have been separated according to charge by isoelectric focusing or chromatofocusing techniques (Keel and Grotjan, 1989). Affinity chromatography using Con $\mathrm{A}$ has also revealed the existence of rat pituitary and plasma $\mathrm{LH}$ glycoforms with different glycoconjugate oligomannose structures (Hattori et al., 1988; Snyder et al., 1989; Papandreou et al., 1993). The relative proportion of gonadotrophin glycoforms, as determined by charge, that are present in the pituitary gland and plasma can alter with the endocrine state (for example, during the 
Table 3. The effect of pituitary and plasma LH on ovulation in rats (22-23 days old) treated with pregnant mares' serum gonadotrophin

\begin{tabular}{|c|c|c|}
\hline $\begin{array}{l}\text { Dose of } \mathrm{LH} \\
\text { (ng per } 60 \mathrm{~g} \text { rat) }\end{array}$ & $\begin{array}{l}\text { Number of } \\
\text { rats ovulating }\end{array}$ & $\begin{array}{l}\text { Mean number of } \\
\text { eggs per ovulatory rat }\end{array}$ \\
\hline \multicolumn{3}{|l|}{ Pituitary } \\
\hline Saline & $4 / 18(22 \%)$ & $4.75 \pm 2.13$ \\
\hline 12.5 & $0 / 5 \quad(0 \%)$ & None \\
\hline 25.0 & $1 / 7 \quad(14 \%)$ & 10 \\
\hline 50.0 & $4 / 8 \quad(50 \%)$ & $6.5 \pm 1.3$ \\
\hline 100.0 & $4 / 6 \quad(67 \%)^{*}$ & $3.25 \pm 0.6$ \\
\hline 200.0 & $7 / 9(78 \%)^{* *}$ & $6.1 \pm 1.1$ \\
\hline \multicolumn{3}{|l|}{ Plasma } \\
\hline Saline & $4 / 18(22 \%)$ & $4.75 \pm 2.13$ \\
\hline 1.25 & $I / 5 \quad(20 \%)$ & 10 \\
\hline 2.5 & $1 / 5 \quad(20 \%)$ & 10 \\
\hline 5.0 & $3 / 8 \quad(37.5 \%)$ & $7.7 \pm 3.2$ \\
\hline 10.0 & $2 / 11(18 \%)$ & 4.0 \\
\hline 20.0 & $6 / 8 \quad(75 \%)^{* *}$ & $5.3 \pm 1.6$ \\
\hline
\end{tabular}

5 iu PMSG was injected s.c. into all the rats on day 22 or 23 of age. All rats were autopsied three days later and the number of eggs in the oviducts noted. Two days after the PMSG injection, controls received $0.5 \mathrm{ml}$ saline i.v.; they weighed $49.8 \pm 0.87 \mathrm{~g}(n=18)$ on day 22 or 23 and $61.8 \pm 1.36 \mathrm{~g}$ at autopsy. Rats receiving plasma in volumes between 0.2 and $1.0 \mathrm{ml}$ to provide $1.25-20 \mathrm{ng} \mathrm{LH}$ per $60 \mathrm{~g}$ rat weighed $51.8 \pm 0.82 \mathrm{~g}(n=37)$ on day 22 or 23 , and $55.7 \pm 0.80 \mathrm{~g}$ and $61.8 \pm 0.70 \mathrm{~g}$ on the days of injection i.v. and autopsy, respectively. Rats receiving pituitary extract over a concentration range of $12.5-200 \mathrm{ng} \mathrm{LH}(0.5 \mathrm{ml})^{-1}$ per $60 \mathrm{~g}$ rat bodymass weighed $50.6 \pm 0.73 \mathrm{~g}$ $(n=35)$ on day 22 or 2.3 and $55.76 \pm 0.17 \mathrm{~g}$ and $61.5 \pm 0.75 \mathrm{~g}$ on the days of injections i.v. and autopsy, respectively.

$* p<0.05$ and $* * P<0.01$ denote a significant difference in the number of rats ovulating compared with the saline-treated group (Fisher's tables).

reproductive cycle or over the peripubertal period; Uchida and Suginami, 1984; Chappel and Ramaley, 1985; Wide, 1985) and in parallel there is a change in biological activity (Reiter et al., 1982; Dufau and Veldhuis, 1987). Since more basic glycoforms are reported to be more biopotent in terms of steroidogenic capacity in vitro, it is likely that the proportion of acid radical terminating groups alters with the endocrine milieu. The relationship between the sugar structures and bioactivity has yet to be unequivocally elucidated.

In this report a comparison was made between the forms of LH in the pituitary gland and plasma. The anion-exchange technique using DE52 resin was originally intended as a preparatory step before investigating LH from the two tissue sources with lectin affinity chromatography. This anionexchange method is inappropriate to effect separation of glycoforms with respect to specific glycosyl structures, but revealed that while pituitary LH was completely adsorbed to the resin, most of the plasma LH was not. It is unlikely that this is artefactual, since all samples were pre-dialysed to minimize the amount of proteins present with a lower molecular weight and unbound plasma LH remained unbound when such fractions were pooled and re-applied to a fresh column. It is also unlikely that $\mathrm{pH}$ differences accounted for the differential binding, since this was monitored carefully and maintained at $\mathrm{pH} 7.4$ for all the samples.
The differential binding may be independent of charge but if it is related to differential charge, there may be a modification of the glycoconjugates with a reduction in acid radicals on release from the pituitary. LH released from rat pituitary glands in vitro is more basic than the stored pituitary LH (Baldwin et al., 1986; Leigh et al., 1991). The fact that LH undergoes some change in structure on secretion has been suggested by others who compared the affinity binding half-lifes, molecular weight or charge of stored and released LH glycoforms both in vivo and in vitro (Campbell et al., 1978a, b; Reddy and Menon, 1981; Baldwin et al., 1986; Papandreou et al., 1993). The role of endocrine control in this conversion was investigated by using several animal models to assess the involvement of gonadal steroids. Results showed that the presence of circulatory steroids did not affect LH glycoform composition: the proportions of unbound and bound plasma LH were not significantly different in intact pro-oestrous adult and untreated immature females, or in ovariectomized rats whether untreated or primed with steroids exerting either a negative or positive feedback effect. Similarly, there was no change in pituitary $\mathrm{LH}$, which remained totally bound in all endocrine models.

Only treatment with PMSG induced a difference in the proportion of unbound and bound plasma $\mathrm{LH}$, with a significant increase noticeable in the bound form compared with the plasma LH obtained from the other endocrine models. Gel filtration showed that this bound plasma was more similar to unbound plasma LH than to bound pituitary $\mathrm{LH}$, implying that it had also undergone a degree of structural change on secretion.

Gel filtration of pituitary and plasma LH showed that they eluted closely (but not exactly) together, indicating that their molecular weights were not greatly different, thus eliminating the possibilities of aggregation, division into subunits or major structural changes. The behaviour of glycoproteins on Sephadex resin is not necessarily representative of molecular weight, since the glycosylation affects filtration characteristics in an unpredictable manner (Kobata, 1990). Thus, even though molecular size markers were used, no truly valid quantitation of molecular weight differences can be made. LH elution peaks in our profiles occurred after the BSA marker at a similar point to those reported elsewhere (Mukhopadhyay et al., 1979; Baldwin et al., 1986). However, the small difference in elution volume between the pituitary and plasma $\mathrm{LH}$ does suggest some discrete structural or conformational differences and that the plasma LH may undergo a conversion that decreases its molecular size very slightly as well as inducing an alteration in its net molecular charge. The bound form of LH noted in plasma (of which approximately $10 \%$ is bound) differs from the bound form of LH obtained from the pituitary gland, since it elutes from a gel filtration column marginally later than does whole-plasma LH.

LH from both pituitary gland and plasma sources contains $N$-linked glycosyl residues with inner core fucosylation, since both tissues yielded LH that bound to Con $\mathrm{A}$ and was eluted at similar points after application of $200 \mathrm{mmol}$ mannose $1^{-1}$, the plasma form appearing approximately $3 \mathrm{ml}$ earlier than the pituitary form. Further experiments using a mannose gradient will reveal whether the multiple glycoforms from the two sources can be separated according to their affinity to the lectin. Papandreou et al. (1993) indicate that this is possible: using two 
concentrations of sugar they eluted human plasma and pituitary LH from Con A columns and found unbound, weakly and firmly bound forms, with a greater predominance of the unbound form in plasma LH. These authors and Snyder et al. (1989) associated the reduced affinity with an increase in negative charge, but others reported that lectin binding characteristics are independent of acid radicals (Hajdukovic et al., 1988; Kobata and Yamashita, 1988).

The sugar specificity of the Glycine maximus column is galactosamine (or $\mathrm{N}$-acetylated galactosamine). While plasma LH did not react with Glycine maximus, approximately $20 \%$ of the pituitary LH bound to the lectin. This indicates that some of the pituitary LH bears glycosyl attachments terminating in an exposed GalNAc residue, while in plasma LH the terminal grouping is absent; perhaps the pituitary LH form is still at an intermediate stage in the glycosylation biosynthetic pathway.

More basic forms of $\mathrm{LH}$ are reported to possess a greater steroidogenic bioactivity (Lichtenberg et al., 1984; Hattori et al., 1988 ) and studies in vitro have shown that pituitary glands release a more basic form of $\mathrm{LH}$ with a greater steroidogenic bioactivity in vitro than that stored in the gland (Mukhopadyhay et al., 1979; Baldwin et al., 1986). We have found that LH derived from pro-oestrous plasma is at least twice as active as pro-oestrous pituitary LH in its ability to stimulate testosterone production from Leydig cells and progesterone production from granulosa cells in vitro. $\mathrm{LH}$ derived from plasma was also more effective than pituitary $\mathrm{LH}$ in inducing ovulation in vivo, since $20 \mathrm{ng}$ plasma $\mathrm{LH}$ and $100 \mathrm{ng}$ pituitary LH (both given per $60 \mathrm{~g}$ bodymass) were the minimum doses showing a significant activity. Even taking bodymass into account, both these doses are considerably lower than the i.v. injection of $1 \mu \mathrm{g}$ purified rat pituitary LH (NIDDK-rLH-I-7) per adult rat needed to induce ovulation in pentobarbitone-treated pro-oestrous rats (Ishikawa, 1992). The enhanced activity may be due to potentiating factors in whole pituitary extract. Similarly, the greater effect of plasma LH over pituitary LH as assessed both in vitro or in vivo may be due to factors present exclusively in adult plasma. However, up to $8 \%$ plasma does not interfere with the Leydig cell bioassay (Tsatsoulis et al., 1990) and so discrepancies in activity of plasma and pituitary LH (at least on steroidogenesis) may well be due to structural differences.

Increased steroidogenic activity of plasma LH was noted only in endocrine states of enhanced LH release, such as on the evening of pro-oestrus and in ovariectomized rats treated with oestrogen and progesterone. When LH release was inhibited, as in untreated immature rats or in ovariectomized rats treated with oestrogen alone, steroidogenic biopotency of bound pituitary and unbound plasma LH were similar; however, this relative reduction in bioactivity of the unbound $\mathrm{LH}$ in these two models may be masked in vivo since after anion-exchange separation another agent appeared to be present in the plasma that was tightly bound to the DE52 resin, not recognized immunogenically as $\mathrm{LH}$, but that had steroidogenic activity as measured by the Leydig cell bioassay. A monoclonal LH antibody has been used to detect a human genetic variant that was not recognized immunologically but that had normal steroidogenic bioactivity (Pettersson and Soderholm, 1991; Pettersson et al., 1991). Similarly, we also detected a steroidogenically active form of $\mathrm{LH}$ in immature PMSG- treated rats that was not recognized by a polyclonal antibody (NIAMMD-S3), although it could be detected by another polyclonal antibody (No. 15; antiserum to ovine $\mathrm{LH}$ ) (Buckingham and Wilson, 1985). An alternative possibility is that this steroidogenic factor is not LH at all, but another negatively charged molecule.

Factors controlling the change in structure, charge and bioactivity of pituitary LH to that of plasma $\mathrm{LH}$ forms in vivo remain unidentified. We have shown that gonadal steroids do not appear to affect charge, as they do not alter pituitary and plasma $\mathrm{LH}$ anion-exchange profiles obtained from rats in different endocrine conditions. The change in bioactivity noted in unbound plasma LH at times of enhanced release may be due to the steroids acting directly at the pituitary level or due to their indirect effect at the hypothalamic level, enhancing gonadotrophin-releasing hormone $(\mathrm{GnRH})$ release. This effect at the hypothalamic level has been suggested by Tsatsoulis $e t$ al. (1991) to explain the variation in B:I ratios of human plasma $\mathrm{LH}$ in different endocrine states and dysfunction, and by Ulloa-Aguirre et al. (1992) for changes in biological activity of rat plasma FSH. GnRH is known to modify glycosylation (Liu et al., 1976; Vogel et al., 1986) and sulfation (Sardanons et al., 1987), both of which would affect steroidogenic bioactivity. $\mathrm{GnRH}$ also alters the binding to an anionic exchange resin of LH glycoforms released in vitro from perifused rat pituitary glands (Leigh et al., 1991). Steroids can influence the bioactivity of LH released from rat pituitary glands in vitro (Mukhopadyhay et al., 1979); they too may act at the pituitary level to influence enzymes involved in glycosylation (Liu and Jackson, 1977) or to stabilize mRNA encoding $\alpha$ and $\beta$ subunits (Paul et al., 1990), both ultimately affecting post-translational processing. Probably a combination of indirect hypothalamic and direct pituitary effects of steroids are involved.

In conclusion, these results show that pituitary $\mathrm{LH}$ undergoes a conversion on release into the plasma that involves a change in its binding characteristics to an anionic ion-exchange resin, and that this is independent of steroidal control, although it can be modified slightly by PMSG. In conditions of enhanced $\mathrm{LH}$ release, the steroidogenic biocompetence of plasma $\mathrm{LH}$ is greater than that of $\mathrm{LH}$ stored in the pituitary. In conditions of reduced LH release, the steroidogenic activities of immunogenic pituitary and plasma LH are similar, and another 'factor' with steroidogenic activity appears in the plasma that is not recognized immunogenically as LH. These changes appear to be endocrine dependent and may be due to a direct effect of gonadal steroids (or some other agents present in the circulation) at the pituitary level, or to an indirect effect exerted by first manipulating $\mathrm{GnRH}$ release. Only minor differences were seen between pituitary and plasma LH after separation by gel filtration or lectin affinity chromatography, showing that only subtle modifications of the structure of $\mathrm{LH}$ are responsible for the differences noted in the pituitary- and plasma-derived LH samples.

The authors are grateful to the Wellcome Trust for their generous support.

\section{References}

Baenziger JU and Green ED (1988) Pituitary glycoprotein hormone oligosaccharides: structure, synthesis, function of the asparagine linked 
oligosaccharides on lutropin, follitropin and thyrotropin Biochimica et Biophysica Acta 947 287-306

Baldwin DM, Highsmith RF, Ramey JW and Krummen LA (1986) An in vitro study of $\mathrm{LH}$ release, synthesis and heterogeneity in pituitaries from proestrous and short-term ovariectomized rats Biology of Reproduction 34 304-315

Buckingham JC and Wilson CA (1985) Peripubertal changes in the nature of luteinizing hormone Joumal of Endocrinology 104 173-177

Campbell GT, Nansel DD, Meinzer WM, III, Aiyer MS and Bogdanove EM (1978a) Prolonged infusion of rat luteinizing hormone alters its metabolic clearance pattern: indirect evidence for postsecretory mutation of luteinizing hormone Endocrinology 103 683-693

Campbell GT, Blair ED, Grossman GH, Miller AE, Small ME and Bogdanove EM (1978b) Distribution and disappearance of radioimmunoassayable circulating luteinizing hormone in the rat: an apparent difference between stored and released forms of the hormone Endocrinology $100674-682$

Chappel SC and Ramaley JA (1985) Changes in the isoelectric focusing profile of pituitary follicle-stimulating hormone in the developing male rat Biology of Reproduction 32 567-573

Chowdhury M, Grotjan HE, Jr and Steinberger E (1982) Further characterization of the molecular species formed during the biosynthesis of rat luteinizing hormone Joumal of Endocrinology 93 169-176

Dufau ML and Veldhuis JD (1987) Pathophysiological relationships between the biological and immunological activities of luteinizing hormone Bailliere's Clinical Endocrinology and Metabolism 1 153-177

Grotjan HE, Jr (1989) Oligosaccharide structures of the anterior pituitary and placental glycoprotein hormones. In Microheterogeneity of Glycoprotein Hormones pp 23-53 Eds BA Keel and HE Grotjan. CRC Press, Florida

Hajdukovic L, Cuperlovic M and Movesijan M (1988) Microheterogeneity of pituitary gland hormones identified by lectin affinity chromatography. In Lectins - Biology, Biochemistry, Clinical Biochemistry pp 511-515 Eds TC Bog-Hansen and DJL Freed. Sigma Chemical Co., Missouri

Hattori MA, Ozawa K and Wakabayashi K (1988) Isoelectric properties, lectin binding characteristics and biological activities of neuraminidase-treated rat LH components Acta Endocrinologica 117 73-79

Ishikawa J (1992) Luteinizing hormone requirements for ovulation in the rat Biology of Reproduction 46 1144-1150

Keel BA and Grotjan HE (1989) Luteinizing hormone microheterogenity. In Microheterogeneity of Glycoprotein Hormones pp 150-184 Eds BA Keel and HE Grotjan. CRC Press, Florida

Kobata A (1990) Structures and functions of the sugar chains of human chorionic gonadotrophin. In Glycoprotein Hormones pp 19-26 Eds WW Chin and I Boime. Serono Symposium, Massachusetts

Kobata A and Yamashita K (1988) Affinity chromatrography of oligosaccharides on E4-phytohemagglutinin-Agarose columns. In Methods in Enzymology: Complex Carbohydrates pp 46-54 Ed. V Ginsberg. Academic Press

Leigh AJ, Wilson CA, Edger MJ, Tipping KE, Patel M, Chapman AJ and Whitehead SA (1991) Stimulation of Juteinizing hormone- $\beta$ messenger ribonucleic acid and post-translational modification of luteinizing hormone isoforms by second messengers mediating the action of gonadotrophin-releasing hormone Joumal of Neuroendocrinology 3 605-611

Lichtenberg V, Weise HC, Schumacher M and Wollring C (1982) Analysis of human pituitary LH isohormones by radioimmunoassay and different in vitro bioassays Acta Endocrinologica Supplementum 246 91-92

Lichtenberg V, Weise HC, Graesslin D and Bettendorf G (1984) Polymorphism of human pituitary lutropin (LH); Effect of the seven isohormones on mouse Leydig cell functions FEBS Letters 169 21-24

Liu TC and Jackson GL (1977) Effect of in vivo treatment with estrogen on luteinising hormone synthesis and release by rat pituitaries in vitro Endocrinology 100 1294-1302

Liu TC, Jackson GL and Gorski J (1976) Effect of synthetic gonadotrophinreleasing hormone on incorporation of radio-active glucosamine and amino acids into luteinizing hormone and total protein by rat pituitaries in vitro Endocrinology 98 151-163

Mukhopadyhay AK, Leidenberger FA and Lichtenberg V (1979) A comparison of bioactivity and immunoactivity of luteinizing hormone stored in and released in vitro from pituitary glands of rat under various gonadal states Endocrinology 104 925-931
Papandreou M-J, Asteria C, Pettersson K, Ronin C and Beck-Peccoz P (1993) Concanavalin A affinity chromatography of human serum gonadotrophins: evidence for changes of carbohydrate structure in different clinical conditions Joumal of Clinical Endocrinology and Metabolism 76 1008-1013

Paul SJ, Ortolano GH, Haisenleder PJ, Stewart JM, Shipnik MA and Marshall JC (1990) Gonadotrophin messenger RNA subunit concentration after blockade of GnRH action: testosterone selectively increases follicle stimulating hormone $\beta$-subunit messenger RNA by post-transcriptional mechanisms Molecular Endocrinology 4 1943-1955

Pharmacia (1991) Affinity Chromatography: Principles and Methods. Pharmacia, Uppsala

Pettersson KMI and Soderholm JRM (1991) Individual differences in lutropin immunoreactivity revealed by monoclonal antibodies Clinical Chemistry 37 333-340

Pettersson K, Ding Y-Q and Huhtaniemi I (1991) Monoclonal antibody based discrepancies between two-site immunometric tests for lutropin Clinical Chemistry 37 1745-1748

Reddy PV and Menon KMJ (1981) Existence of multiple molecular forms of luteinizing hormone in rat: differences in immunological and biological activities between stored and circulating forms Acta Endocrinologica 97 33-41

Reiter HW, Beitins IZ, Ostrea T and Gutai JP (1982) Bioassayable luteinizing hormone during childhood and adolescence and in patients with delayed pubertal development Journal of Clinical Endocrinology and Metabolism 54 $155-161$

Sardanons ML, Solano AR and Podesta EJ (1987) Gonadotrophin-releasing hormone action upon luteinizing hormone bioactivity in pituitary gland: role of sulphation Journal of Biological Chemistry 26211 149-11 155

Snyder PJ, Bashey JM, Montecinos A, Odell WD and Spitalnick SL (1989) Secretion of multiple forms of human luteinizing hormone by cultured fetal human pituitary cells Joumal of Clinical Endocrinology and Metabolism 68 1033-1038

Stockell Hartree A, Lester JB and Shownkeen RC (1985) Studies of the heterogeneity of human pituitary LH by fast protein liquid chromatography Journal of Endocrinology 105 405-413

Tsatsoulis A, Shalet SM, Richardson P \& Robertson WR (1990) Testosterone reduces the bioactivity of luteinizing hormone $(\mathrm{LH})$ in man Clinical Endocrinology 32 73-82

Tsatsoulis A, Shalet SM and Robertson WR (1991) Bioactive gonadotrophin secretion in man Clinical Endocrinology 35 193-201

Uchida H \& Suginami H (1984) Subpopulations of luteinizing hormone (LH) possessing various ratios of bioactivity to immunoreactivity in the female rat pituitary glands and their changes during the estrous cycle Endocrinologia Japonica $31605-618$

Ulloa-Aguirre A, Schwall R, Cravioto A, Zambrano E and Damian-Matsumura P (1992) Effect of gonadotrophin-releasing hormone, recombinant human activin- $A$ and sex steroid hormones upon the follicle-stimulating isohormones secreted by rat anterior pituitary cells in culture Journal of Endocrinology 134 97-106

van Damme M-P, Robertson DM and Diczfalusy E (1974) An improved in vitro bioassay method for measuring luteinizing hormone (LH) activity using mouse Leydig cell preparations Acta Endocrinologica 77 655-671

Vogel DL, Magner JA, Sherins RJ and Weintraub BD (1986) Biosynthesis, glycosylation, and secretion of rat luteinizing hormone $\alpha$ - and $\beta$-subunits: differential effects of orchidectomy and gonadotropin-releasing hormone Endocrinology 119 202-213

Wakabayashi K (1977) Heterogeneity of rat luteinizing hormone revealed by radioimmunoassay and electrofocusing studies Endocrinologia Japonica 24 $473-485$

Wide L (1985) Median charge and charge heterogeneity of human pituitary FSH, LH and TSH. II. Relationship to sex and age Acta Endocrinologica 109 190-197

Wilson CA, Buckingham JC and Morris ID (1985) The influence of growth hormone corticosterone, corticotrophin and changes in environmental temperature on pituitary-ovarian function in the immature rat Journal of Endocrinology 104 179-183

Wilson CA, Leigh AJ and Chapman AJ (1990) Gonadotrophin glycosylation and function: a review Journal of Endocrinology 125 3-14 